\title{
Double Income Taxation Treaties: The O.E.C.D. Draft ${ }^{\dagger}$
}

\author{
Adrian A. Kragen*
}

TN 1939 the United States entered into its first comprehensive international treaty ${ }^{1}$ to prevent or mitigate double taxation of income. ${ }^{2}$ It has been recently announced that this pioneer in United States income tax treaties has been renegotiated and modernized to conform to modern developments and to meet some situations not covered in the original docunient. ${ }^{3}$ Twenty-five years of international double taxation agreements has convinced many businessmen and tax experts of the importance of this type of arrangement but has left unanswered many of the problems which the increase in international trade and travel and the diversity of tax systems have brought into focus. The United States Treasury Department has been engaged in a series of studies of the possibility of increasing uniformity in double taxation treaties and, in addition, has actively participated in the work of the Organization for Economic Co-operation and Development Fiscal Committee (O.E.C.D.). These activities are directed toward, and motivated by the need for eliminating the complexities of many of our present treaties-complexities which, to some extent, have undercut the treaty purpose.

Although the United States came into the tax treaty picture comparatively late, it had given some double taxation relief to its citizens and residents by a tax credit procedure as early as $1918^{4}$ and since 1862 has provided a deduction for foreign taxes paid by its citizens. ${ }^{5}$ The tax credit system, which in its present form was incorporated in the 1939 Internal

$\dagger$ The author in 1962 visited nine Western European countries and discussed the operation of tax treaties with governmental and private tax authorities. Some of the comments in this article emanated from these discussions. The visit to Denmark was in part financed by a grant from the Rask $\emptyset$ rsted Foumdation. Financial assistance was also received froun the Committce on International Legal Studies of the School of Law, University of California, Berkeley, from funds furnished by the Ford Foundation.

* B.A., 1931, LL.B., 1934, University of California, Berkeley ; Professor of Law, University of California School of Law, Berkeley.

1 Convention and Protocol With Sweden Respecting Double Taxation, March 23, 1939, 54 Stat. 1759, T.S. No. 958.

2 The words "treaty" and "convention" will be used interchangeably in this article to cover double taxation agreements. The first United States agreement was with France in 1936, but it was very limited in scope. Convention and Protocol With France Respecting Double Taxation, April 27, 1932, 49 Stat. 3145, T.S. No. 885 (effective Jan. 1, 1936).

3 Treas. Announcement 63-123, 1963 INT. REv. BuLL. No. 48, at 12.

4 Revenue Act of 1918, ch. 18, \$\$ 222, 238, 40 Stat. 1073, 1080.

5 Act of 1862 , ch. 119, § 91, 12 Stat. 432 . 
Revenue Code, ${ }^{6}$ has reduced materially the impact of foreign taxes on United States citizens but has not, in the opinion of this writer, eliminated to any appreciable extent the need for tax treaties in international commerce. $^{7}$

There is evidence of reciprocal tax relief in Holland as early as $1819^{8}$ and special provisions in Belgium, Norway, Switzerland and other countries in the late 19th or early 20th Century. Actual double tax agreements were executed between Austria-Hungary and the German States in the late 19th Century, Austria and Greece in 1902, and Switzerland and Italy in $1904 .^{\circ}$ Although there were others in the same general period, it is clear that no concerted effort to secure the adoption of double taxation conventions was initiated prior to the end of World War I. At that time the International Chamber of Commerce was organized and made as one of its major objectives the securing of agreements to prevent double taxation. In 1922 the League of Nations undertook a study of the problem and appointed technical experts who in 1925 filed a report suggesting, among other things, the authorization of a group of technical experts to prepare a draft convention. Between the close of World War I and the time that report was made, some treaties had been entered into, and by 1930 the number of these had substantially increased. In 1928 the League of Nations Committee of Technical Experts produced its first draft and since that time the committee and its lineal descendants have produced a number of "model" convention drafts, parts of which have been adopted in the conventions executed after their publication. The Model Conventions of Mexico (1943) and London (1946) have been very instrumental in bringing some semblance of uniformity to the bilateral conventions executed in the post-war period. But there are still a large number of differences in the provisions of existing treaties. The result is a considerable area of uncertainty which plagues United States taxpayers doing business in European countries, and European taxpayers doing business in the United States and other European countries. It was the realization of the increasing importance of this impediment to international commercial transactions that prompted the creation of the Fiscal Committee of the Organization for European Economic Cooperation (O.E.E.C.) by the O.E.E.C. Council in 1956 to study fiscal questions relating to double tax-

O Int. Rev. CODE of 1939, ch. $2, \S 23,53$ Stat. 1.

7 But see Owens, Role of the United States Income Tax Treaties in Relieving Double. Taxation, 4 Institute on Private Invesmaents ABroad 109 (1962). In this article, Mrs. Owens suggests in part that the treaties have a minimal effect in relieving double taxation and that the United States may be giving up too mucl just to obtain an income tax treaty.

8 Herndon, Relmef Fron International Inconte Taxation 11 (1932).

9 Id. at $16-17$. 
ation. ${ }^{10}$ The significance of this study is emphasized when we consider that the O.E.E.C. includes Austria, Belgium, Denmark, France, Germany, Greece, Iceland, Ireland, Italy, Luxembourg, the Netherlands, Norway, Portugal, Spain, Sweden, Switzerland, Turkey, and the United Kingdom. In addition, the United States and Canada have participated continuously in the deliberations.

The committee initially took as a major objective drafting a series of treaty articles which could be used as a model bilateral convention with the hope that the adoption of these articles by a large number of countries would eventually lead to the adoption of a single multilateral convention. ${ }^{11}$ The Fiscal Committee has now completed the first part of the work and has issued a final report on this aspect of its study. It should be noted that although the Fiscal Committee started as a committee of the O.E.E.C., in December 1960 the O.E.C.D. was formed which included as members the O.E.E.C. countries plus Canada and the United States. The Fiscal Committee continued as an arm of this new organization and the report is issued in its name. This report is the culmination of the study reports issued in 1958, 1959, 1960, and 1961 and brings together in one publication the basic materials contained in those reports and the complete text of the Draft Double Taxation Convention. ${ }^{12}$

It is the purpose of this article to discuss somewhat briefly a number of the more important provisions of the Draft Double Taxation Convention, to compare them with the corresponding provisions, if any, in existing United States conventions, and to consider whether the provisions suggested by the Fiscal Committee would meet the problems encountered in the operation of the Umited States agreements. ${ }^{13}$ It should be noted that the Fiscal Committee report indicates some substantial reservations by the United States and some other participating nations to specific articles of the draft treaty. ${ }^{14}$ Although these reservations would appear to mitigate against United States inclusion in the hoped for multilateral convention, they at least pinpoint the basic differences between the United States' position and those of the other participating members on specific items. They thus offer some opportunity for future negotiation. ${ }^{15}$

Article 1 of the draft provides that the convention applies to residents

${ }^{10}$ Organization for Economic Co-operation and Development Fiscal Committee, Report, Draft Double Taxation Convention 7 (1963) (hereinafter cited as OECD Report).

11 Id. at 10.

12 Id. at $41-58$.

13 Id. at 19.

14 The United States has adopted generally the approach that its treaties deal with inatters beneficial to the contracting parties and do not bring into automatic inclusion nations which have "most favored nations" clauses in their treaties. But see, BITTKER \& EBb, TAXATTON of FOREIGN INCOME 394 (1960).

15 OECD Report 19. 
of one of the contracting countries. Article 4 defines residence with considerably more particularity than any present United States treaty. ${ }^{16}$ An adequate definition of residence is essential in this period of ever faster modes of transportation. We now transport individuals from San Francisco to Stockholm in less time than normally was consumed in going from New York to Chicago at the time our first tax treaty was executed. There are now individuals with dwellings in California and Florida, castles in Austria, and shooting lodges in Scotland. The problem of dual and even quadruple residence is with us and the problems which result make essential to any tax treaty as specific a definition of residence as is possible. ${ }^{17}$ The draft sets forth three criteria for determining residence. Primarily, the individual is treated as a resident where he has his permanent home. If we have the situation of the dwelling in California and the castle in Austria, both of which are permanent homes, the draft chooses as residence the country in which the home is situated with which the taxpayer has the closest personal and economic interest ("centre of vital interests"). If the individual has no permanent home or his "centre of vital interests" cannot

\footnotetext{
10 Id. at 41,43 .

"Article 1-Personal Scope

This Convention shall apply to persons who are residents of one or both of the Contracting States."

"Article 4-Fiscal Domicile

1. For the purposes of this Convention, the term 'resident of a Contracting State' means any person who, under the law of that State, is liable to taxation therein by reason of his domicile, residence, place of management or any other criterion of a similar nature.

2. Where by reason of the provisions of paragraph 1 an individual is a resident of both Contracting States, then this case shall be determined in accordance with the following rules:

a) He shall be deemed to be a resident of the Contracting State in which he has a permanent home available to him. If he has a permanent home available to him in both Contracting States, he shall be deemed to be a resident of the Contracting State with which his personal and economic relations are closest (centre of vital interests);

b) If the Contracting State in which he has his centre of vital interests cannot be determined, or if he has not a permanent home available to him in either Contracting State, he shall be deemed to be a resident of the Contracting State in which he has an habitual abode;

c) If he has an habitual abode in both Contracting States or in neither of them, he shall be deemed to be a resident of the Contracting State of which he is a national;

d) If he is a national of both Contracting States or of neither of them, the competent authorities of the Contracting States shall settle the question by mutual agreement.

3. Where by reason of the provisions of paragraph 1 a person other than an mdividual is a resident of both Contracting States, then it shall be deemed to be a resident of the Contracting State in which its place of effective management is situated."

17 This definition would have prevented the nearly complete exeinption from income taxation which the differing concepts of residence in the United Kingdom and the United States gave certain taxpayers. See David Rose, 16 T.C. 232 (1951) ; McMahon v. Minister of Nat'1 Revenue [1959] Can. Tax App. Bd. 166; Swedish Cent. Ry. v. Thompson [1925] A.C. 495. The definition would appear to be a solution to the theoretical problem of alloeation presented in Wang, International Double Taxation of Income: Relief through International Agreement 1921-1945, 59 HARv. L. REv. 73, 75 (1945).
} 
be determined then his habitual abode is considered his residence. Finally, if he has a habitual abode in both countries he is deemed a resident of the one of which he is a national. An examination of these alternatives indicates that although there is no logical reason why the United States could not adopt this definition in income tax treaties, it could not be accepted as a test of tax liability without modifying our traditional use of citizenship for determining hability for income tax. The United States taxes all its citizens on all income not specifically exempted by statute, regardless of source and of the place of residence of the citizen. The United States has, therefore, reserved its approval of this article of the draft and thus implies its intention to maintain its traditional concept in any negotiation of tax treaties. It is unlikely that this position will be changed.

The adoption of the draft's definition would certainly assist in bringing about uniformity, but it would also allow wealthy United States citizens to establish their principal residence in low tax rate countries and obtain very substantial benefits by reason of the convention provisions. There is no indication that the United States is interested enough in uniformity of tax treaty provisions to afford this tax saving opportunity to its citizens. ${ }^{18}$ Thus, the United States probably would not enter into a uniform multilateral treaty embodying this draft provision. The definition of residence in article 4 does seem to be appropriate, however, for insertion in United States treaties as a means of solving difficult definitional questions without derogating the right of the United States to tax its citizens. It might, for example, be useful for the interpretation of "residence" as used in Section 911(a)(1) of the Internal Revenue Code of 1954. It certainly would be of assistance in determining the difficult problem of the alien with dual "residences" who actually lives in each contracting country for a substantial period but has substantially more personal and economic ties in one of the countries. Recently the author was faced with the problem of a professor who is a citizen of Switzerland where he owns a dwelling - presently rented to a third party - who had completed his education and been employed for four years in the United Kingdom. After temporary employment of a year in the United States he was endeavoring to obtain a tax clearance in order to accept employment in France. The United States had treaties with all three countries with differing terminology and with

18 The United States has usually provided a savings clause in tax treaties allowing it to tax its citizens and residents as if the treaty had not been in effect. Marie G. Crerar, 26 T.C. 702 (1956). But see Convention With Austria for the Avoidance of Double Taxation, Oct. 25, 1956, art. XV, para. 1, [1957] 2 U.S.T. \& O.I.A. 1699, 1708, T.I.A.S. No. 3923 (citizens only); Convention With Pakistan for the Avoidance of Double Taxation, July 1, 1957, [1959] 1 U.S.T. \& O.I.A. 984, T.I.A.S. No. 4232 (no savings clause). The Protocol to the 1939 Swedish treaty provides for inclusion of citizens of either Sweden or the United States who are resident in a third country. Convention With Sweden for the Avoidance of Double Taxation, March 23, 1939, Protocol para. 3, 54 Stat. 1759, T.S. No. 958. 
no definition of residence. As a result the Internal Revenue Service took the position that the individual was not a resident of any one of the three countries for purposes of the treaty provisions on professors. The draft clause would have covered this problem and many others which have arisen because of the absence of any treaty definition and because there is no standard definition of residence in internal tax laws of the contracting countries. Although United States policy and treaty makers might be reluctant, due to the present concern with the "flight" of the dollar and with the tax haven problenı, to include any definition which might encourage residence in a foreign country while retaining sone ties with the United States, this should not be a substantial obstacle to use of the definition for purposes other than determining tax liability of citizens. Although we presently have treaties with countries using the permanent hoine concept as the criterion for residence, there have been situations, largely settled on an ad hoc basis, which have been the source of minor irritation in tax offices of these countries. ${ }^{19}$

Article 2 provides that the convention shall apply to taxes on income and on capital imposed by the contracting states, their political subdivisions, or local authorities. ${ }^{20}$ It recognizes the need for something more than a general statenient as to the nature of the taxes covered. ${ }^{21}$ A specific illus-

19 One situation which no United States treaty covers is that of the United States citizen who, after divorce, returns to her native country and receives alimony from her ex-spouse.

20 OECD Report 41. "Article 2-Taxes covered

1. This Convention shall apply to taxes on income and on capital imposed on behalf of each Contracting State or of its political subdivisions or local authorities, irrespective of the manner in which they are levied.

2. There shall be regarded as taxes on income and on capital all taxes imposed on total incone, on total capital, or on elements of income or of capital, including taxes on gains from the alienation of movable or immovable property, taxes on the total amounts of wages or salaries paid by enterprises, as well as taxes on capital appreciation.

3. The existing taxes to which the Convention shall apply are, in patricular:

a) in the case of (State A): ...

b) in the case of (State B): ....

4. The Convention shall also apply to any identical or substantially similar taxes which are subsequently imposed in addition to, or in place of, the existing taxes. At the end of each year, the conipetent authorities of the Contracting States shall notify to each other any changes which have been made in their respective taxation laws."

${ }^{21}$ See Convention With the United Kingdons for the Avoidance of Double Taxation, April 16, 1945, art. I, 60 Stat. 1377, T.I.A.S. No. 1546:

"(1) The taxes which are the subject of the present Convention are:

(a) In the United States of America: The Federal income taxes, including surtaxes and excess profits taxes (hereinafter referred to as United States tax).

(b) In the United Kingdonı of Great Britain and Northern Ireland: The income tax (including surtax), the excess profits tax and the national defense contribution (hereinafter referred to as United Kingdons tax).

(2) The present Convention shall also apply to any other taxes of a substantially similar character imposed by either Contracting Party subsequently to the date of signature of the present Convention or by the government of any territory to which the present Convention is extended under Article XXII." 
trative enumeration of the taxes in effect and within the scope of the treaty would preclude many difficulties of interpretation of the nature of foreign taxes. ${ }^{22}$ The proposal to include taxes imposed by state and local governments would relieve one of the sources of confusion and irritation for individuals residing in treaty countries and working in the Umited States for a period and under conditions which bring them within the treaty exemption from taxation of remuneration for services. When these individuals suddenly find that they are subject to state and sometimes even local income taxes, they are not only financially embarrassed but in many cases emotionally disturbed and bitter. The United States lras never attempted to specifically include in any double taxation treaty the taxes imposed by state or local governments within the United States, although the treaty with Switzerland includes in the Swiss taxes covered those imposed on income by the cantons and communes. ${ }^{23}$ The United States Constitution does not appear to prohibit the inclusion of state and local governments in the governmental units whose taxes are affected by treaties. ${ }^{24}$ The United States, however, lias reserved its position on this part of the article, probably based on considerations of political feasibility rather than constitutional authority.

Article 5 of the draft contains the defimition of permanent establishment. ${ }^{25}$ This is one of the inost important provisions in any tax treaty

22 See for example Rev. Rul. 63-51, INr. REv. BuIr. No. 12 (Belgium Tax Mobiliere and Contribution Nationale de Crise) ; Rev. Rule 58-475, 1958-2 Cun. Buxx. 385 (Canadian insurance premiums tax). Some specificity is present in treaties. See Convention With the Italian Republic for the Avoidance of Double Taxation, March 30, 1955, art. I [1956] 3 U.S.T. \& O.I.A. 2999, T.I.A.S. No. 3679.

${ }^{23}$ Convention With the Swiss Confederation for the Avoidance of Double Taxation, May 24, 1951, art. I [1951] 2 U.S.T. \& O.I.A. 1751, T.I.A.S. No. 2316.

24 Although this question has not been unequivocally determined, the local tax laws would appear subject to the overriding authority of United States treaties. See Missouri v. Holland, 252 U.S. 416 (1919); Scandinavia Air Lines v. Los Angeles, 56 Cal. 2d 11, 37, 363 P.2d 25, 40, 14 Cal. Rptr. 25, 40 (1961). Cf. Peoplé v. Naglee, 1 Cal. 232 (1850).

25 OECD Report 43. "Article 5-Permanent Establishment

1. For the purposes of this Convention, the term 'permanent establishment' means a fixed place of busimess in which the business of the enterprise is wholly or partly carried on.

2. The term 'permanent establishment' shall include especially:

a) a place of management;

b) a branch;

c) an office;

d) a factory;

e) a workshop;

f) a mine, quarry or other place of extraction of natural resources;

g) a building site or construction or assembly project which exists for more than twelve months.

3. The term 'permanent establishment' shall not be deemed to include:

a) the use of facilities solely for the purpose of storage, display or delivery of goods or merchandise belonging to the enterprise; 
because, in general, the taxability of the industrial and commercial profits of a foreign enterprise is dependent upon the presence of a permanent establishment in the taxing country. Most United States bilateral income tax conventions contain a provision similar to article 5, although not as clearly set forth. ${ }^{26}$ The draft provision specifically covers some of the areas in which modern developments have raised disturbing questions. For example, subparagraph 3(e) specifies that the operation of a so-called "propaganda office" in one of the contracting countries shall not constitute, in and of itself, a permanent establishment. The "propaganda office" is a comparatively recent device, used particularly by large American com-

b) the maintenance of a stock of goods or merchandise belonging to the enterprise solely for the purpose of storage, display or delivery;

c) the maintenance of a stock of goods or merchandise belonging to the enterprise solely for the purpose of processing by another enterprise;

d) the maintenance of a fixed place of business solely for the purpose of purchasing goods or merchandise, or for collecting information, for the enterprise;

e) the maintenance of a fixed place of business solely for the purpose of advertising, for the supply of information, for scientific research or for similar activities whicl have a preparatory or ausiliary character, for the enterprise.

4. A person acting in a Contracting State on behalf of an enterprise of the other Contracting State-other than an agent of an independent status to whom paragraph 5 applies-shall be deemed to be a permanent establishment in the first-mentioned State if he has, and habitually exercises in that State, an authority to conclude contracts in the name of the enterprise, unless his activities are limited to the purchase of goods or merchandise for the enterprise.

5. An enterprise of a Contracting State shall not be deemed to have a permanent establishinent in the other Contracting State unerely because it carries on business in that otlier State througl a broker, general commission agent or any other agent of an independent status, where such persons are acting in the ordinary course of their busmess.

6. The fact that a company which is a resident of a Contracting State controls or is controlled by a company which is a resident of the other Contracting State, or which carries on business in that other State (whether through a permanent establishment or otherwise), shall not of itself constitute for either company a permanent establishment of the other."

${ }^{20}$ See, for example, Convention With the Netherlands Respecting Double Taxation, April 29, 1948, art. II, para. (i), 62 Stat. 1757, T.I.A.S. No. 2820, as amended, June 15, 1955 [1955] 3 U.S.T. \& O.I.A. 3696, T.I.A.S. No. 3366: "The term 'permanent establishment,' when used with respect to an enterprise of one of the Contracting States, means a branch, factory, or other fixed place of business, but does not include an agency unless the agent has, and habitually exercises, a general authority to negotiate and conclude contracts on behalf of such enterprise or has a stock of Inerchandise from which he regularly fills orders on bchalf of such enterprise. An enterprise of one of the Contracting States shall not be deemed to have a permanent establishment in the other Contracting State merely because it carries on business dealings in such other Contracting State through a bona fide commission agent, broker or custodian acting in the ordinary course of his business as such. The fact that an enterprise of one of the Contracting States maintains in the other Contracting State a fixed place of business exclusively for the purchase of goods or merchandise shall not of itself constitute such fixed place of business a permanent establishment of such enterprise. When a corporation of one Contracting State has a subsidiary corporation which is a corporation of the other Contracting State or which is engaged in trade or business in such other Contracting State, such subsidiary corporation shall not, merely because of that fact, be deemed to be a permanent establishment of its parent corporation." 
panies, which involves establishing an office in the foreign country (mainly, so far, Brussels and Paris) to handle advertising, marketing research, buying, scientific research, or related activities. Usually the corporation operates its selling or manufacturing activities in the foreign country through a subsidiary, but the "propaganda office" is a direct arm of the parent. With the advent of the European Common Market as an important economic unit, the number of these offices has materially increased. Thus far, these offices generally have not been treated as permanent establishments, and in the one or two instances where they have been so treated, it has been determined that no profits are attributable to the office. ${ }^{27}$ The increase in their size and complexity, however, has created in European tax authorities some inclination to take a second look at this type of operation. Subparagraph 3(e) of the draft clearly eliminates the problem. It also opens the door for more extensive activities, such as the sale of research results by one of these offices, by the words "or for similar activities which have a preparatory or auxiliary character for the enterprise." This language is also intended to exclude from the definition of permanent establishment an office established to service a patent or "know how" agreenient. ${ }^{28}$ It is not, however, intended to exclude an office established principally for the sale of research results. The United States presently appears to take the view that "propaganda offices" which engage in an activity not specifically excepted in a treaty (such as any office for purchase of goods) do constitute permanent establishments. ${ }^{20}$

Article 5 also excludes fron the permanent establishment category an independent agent or one who does not have authority to conclude contracts in the name of the employer other than contracts for purchase of goods for the einployer. ${ }^{30}$ This has been the general rule under the United States treaties, but it has been difficult to apply and easy to avoid. ${ }^{31}$

27 These statements reflect conversations with government representatives in Western European countries and are not reported in any publication seen by the author.

28 OECD Report 74.

29 Rev. Rul. 62-53, 1962-1 Cum. BuLl. 43.

30 See Draft Article 5, para. 4, supra note 25.

31 It has been ruled, for example, that a foreign corporation creates a permanent establishment by baving an independent agent (not an employee) in the Urited States with authority to conclude contracts. Rev. Rul. 54-588, 1954-2 CuM. BuLl. 657. On the other band, a Canadian corporation with a license to do business in Ohio but with no assets, bank account, or office in Ohio was held to have a permanent establisliment in the United States. Commissioner v. Consolidated Premium Ores, Ltd., 265 F.2d 320 (6th Cir. 1959). See McMahon v. Minister of Nat'l Revenue, [1959] Can. Tax App. Bd. 166. The court in Consolidated believed that the term permanent establishment as used in the treaty with Canada implied the existence of a staffed office, able to carry on the corporate business. The Canadian treaty carries a general definition of permanent establislıment with a special clause not found in other treaties under which the use of substantial machinery or equipment is one indication of a permanent establishment. Convention With Canada for the Avoidance of Double Taxation, March 4, 1942, 56 Stat. 1399, T.S. No. 983, as amended, June 12, 1950 [1951] 2 U.S.T. \& O.I.A. 2235, 
Uncertainty still exists under the draft provision as to what is "authority to conclude contracts" and whether the mere formality that contracts must be approved at the home office is sufficient to bring an agency activity within the exclusionary paragraph. There is language in the commentaries indicating that a requirement of formal, but meaningless approval is not sufficient. ${ }^{32}$ Inasmuch as this is one area about which there is substantial question and variation in interpretation under the present treaties, it would be advantageous to have a specific definition of approval which would clearly exclude "paper approvals."

The rule applicable to dependent agents is discussed in the commentaries. ${ }^{33}$ The draftsmen have endeavored to eliminate some of the confusion permeating the application of this type of provision in existing treaties by requiring only authority to conclude contracts rather than general authority. They suggest that agents do not normally have unfettered authority and all that should be needed to qualify under the permanent establishment provision is habitually used authority. It appears doubtful, however, that this effort at a less pervasive requirement will assist in determining the validity and bona fides of restrictions on an agent's authority for purposes of the permanent establishment article.

One item designated as a permanent establishment which, in language at least, is not found in treaties to which the United States is a party is "place of managenient." This term is on its face ambiguous, and the commentary does not adequately explain its meaning, except to say that it is intended to cover the "head office" but may also cover a management center which is not an office. ${ }^{34}$ It is difficult, however, to conceive any modern business in which the place of management does not qualify under the category of office. This is no longer a day when a man carries his business in his derby hat. ${ }^{35}$ There should be a clearer explanation of this category of permanent establishment if it is to be included im future treaties.

T.I.A.S. No. 2347. Under the treaty with France it has been ruled that entry by a French resident of a horse in a single race in the United States constitutes engaging in a trade or business but does not constitute a permanent establishment in the United States. The ruling implies, however, that, under the treaty, entering a horse in two or more races may he sufficient to create a permanent establishment. Rev. Rul. 58-63, 1958-1 CuM. BuLc. 624. See American Wheelabrator v. Minister of Nat'I Revenue, 5 Dom. Tax Cas. 285 (1951). See also Donroy Ltd. v. United States, 301 F.2d 200 (9th Cir. 1962); De Amodio v. Commissioner, 299 F.2d 623 (3d Cir. 1962) ; Inez De Amodio, 34 T.C. 894 (1960) ; Frank Handfield, 23 T.C. 633 (1955); Rev. Rul. 63-113, 1963-1 Cus. Bull. 410; Rev. Rul. 56-594, 1956-2 CuM. Bull. 1126; Rev. Rul. 55-282, 1955-1 Cum. BuLL. 634.

32 OECD Report 75.

33 Ibid.

$34 I d$. at $72-73$.

35 Perhaps the draftsmen were considering the type of situation referred to by Lord Summer in Mitchell v. Egyptian Hotels, Ltd. [1915] A.C. 1022, 1037, when he said, "Where the brain which controls the operation is in this country the enterprise is at any rate partly carried on in this country." 
The draft also adopts a provision similar to that contained in most United States treaties to the effect that the presence of a permanent establishment of a subsidiary in one of the contracting countries does not of itself constitute a permanent establishment of the parent in that country. Thus, if it does not act for the parent and does not have authority to contract in the name of the parent it will not be considered a permanent establishment of the parent for the purpose of attributing a portion of the industrial or commercial profits of the parent to the country involved.

Practitioners have indicated to the author that one of their most difficult problems has been advising clients whether a specific activity constitutes a permanent establishment. The decisions of the courts, although helpful, have touched on only a few of the problems. ${ }^{36}$ Although the more explicit language of the model draft will undoubtedly be of some assistance, it does not appear that the draft has made a material contribution toward the solution of this definitional difficulty. A more comprehensive discussion in the commentaries might give us the benefit of a sort of legislative history which practitioners and the courts could use. Another possibility would be the promulgation with the treaty of a detailed set of regulations like those set out in connection with the United States Internal Revenue Code. This would necessitate, of course, an appropriate delegation of authority in the treaty and could only be successful if the regulations were the product of conference and agreement by the tax authorities of both contracting countries. As a third alternative, the regulation might be drafted by the O.E.C.D. with a provision in the treaty that an adoption of the treaty includes adoption of the regulations. ${ }^{37}$

Article 6 gives the country in which "immovable property" (generally real property) is located the right to tax the income from such property. A similar provision is found in all United States income tax treaties, but the model convention spells it out in greater detail. ${ }^{38}$ The draft article, in

36 Commissioner v. Consolidated Premium Iron Ores, Ltd., 265 F.2d 320 (6th Cir. 1959); Inez De Amadio, 34 T.C. 844 (1960); Frank Handfield, 23 T.C. 633 (1955).

37 A recent United States ruling on Article 10 of the United States Convention With France for the Avoidance of Double Taxation, July 25, 1939, 59 Stat. 893, 899, T.S. No. 988, as amended, Oct. 18, 1946, 64 Stat. (pt. 3) B3, T.I.A.S. No. 1982, May 17, 1948, 64 Stat. (pt.3) B28, B29, T.I.A.S. No. 1982, illustrates the advantages of prior understanding on the jiterpretation of treaty provisions. Rev. Rul. 64-92, 1964 INT. REv. BuLL. No. 12, at 25. In this ruling, the United States adopts the more restricted rule of the French tax authoritics as to the practice of a "liberal profession."

38 OECD Report 45. "Article 6-Income from Immovable Property

1. Income from immovable property nuay be taxed in the Contracting State in which such property is situated.

2. The term 'immovable property' shall be defined in accordance with the law of the Contracting State in which the property in question is situated. The term shall in any case include property accessory to immovable property, livestock and equipment used in agriculture and 
addition, specifically provides that the law of the situs controls the definition of "immovable property" but provides that certain items shall always be considered in this category. For example, it includes property used incidental to "immovable property" such as livestock and equipment used in agriculture. Of course the United States' reservation of its traditional concept of taxation of residents and citizens precludes the provision having any major effect on United States revenue. Although this article would not appear to present any substantial problem to the United States, we have noted our tentative reservation to it. ${ }^{39}$

Article 7 spells out in some detail the rule of attribution of profits from an enterprise, following the general rule in most extant conventions that industrial and commercial profits of an enterprise resident in one contracting state are not taxable in the other contracting state unless the enterprise has a permanent establishment in the other state. ${ }^{40}$ The draft clause

forestry, rights to which the provisions of general law respecting landed property apply, usufruct of immovable property and rights to variable or fixed payments as consideration for the working of, or the right to work, mineral deposits, sources and other natural resources; ships, boats and aircraft shall not be regarded as immovable property.

3. The provisions of paragraph I shall apply to income derived from the direct use, letting, or use in any other form of immovable property.

4. The provisions of paragraphs 1 and 3 shall also apply to the income from immovable property of an enterprise and to income from immovable property used for the performance of professional services."

Compare this provision with Convention With the Netherlands for the Avoidance of Double Taxation, April 29, 1948, art. V, 62 Stat. 1757, 1760, T.I.A.S. No. 1855: "Income of whatever nature derived from real property and interest from mortgages secured by real property shall be taxable only in the Contracting State in which the real property is situated."

39 OECD Report 19.

40 Id. at 45. "Article 7-Business Profits

1. The profits of an enterprise of a Contracting State shall be taxable only in that State unless the enterprise carries on business in the other Contracting State through a permanent establishment situated therein. If the enterprise carries on business as aforesaid, the profits of the enterprise may be taxed in the other State but only so much of them as is attributable to that permanent establishment.

2. Where an enterprise of a Contracting State carries on busimess in the other Contracting State through a permanent establishment situated therein, there shall in each Contracting State be attributable to that permanent establishment the profits which it might be expected to make if it were a distinct and separate enterprise engaged im the same or similar activities under the same or similar conditions and dealing wholly independently with the enterprise of which it is a permanent establishment.

3. In the determination of the profits of a permanent establishment, there shall be allowed as deductions expenses which are incurred for the purposes of the permanent establishment including executive and general administrative expenses so incurred, whether in the State in which the permanent establishment is situated or elsewhere.

4. Insofar as it has been customary in a Contracting State to determine the profits to be attributed to a permanent establishment on the basis of an apportionment of the total profits of the enterprise to its various parts, nothing in paragraph 2 shall preclude that Contracting State 
is much more explicit than that found in many United States conventions. ${ }^{41}$ One of the most important aspects of the draft provision is that only that portion of the profits which are attributable to the permanent establishment may be taxed in the State in which the permanent establishment is located. This is contrary to the express provision in some United States conventions ${ }^{42}$ and to the Umited States' interpretation when the convention is silent in this regard. ${ }^{43}$ It has been the Umited States' position that if a convention country enterprise has a permanent establishment in the United States, and the treaty does not provide otherwise, all profits of the enterprise emanating from United States sources are subject to United States taxation. The attitude has been resented not only by the enterprises affected but by foreign tax officials bearing the brunt of complaints by their nationals. The Umited States has indicated its reservation to the draft

from determining the profits to be taxed by such an apportionment as may be customary; the method of apportionment adopted shall, however, be such that the result shall be in accordance with the principles laid down in this Article.

5. No profits shall be attributed to a permanent establishment by reason of the mere purchase by that permanent establishment of goods or merchandise for the enterprise.

6. For the purposes of the preceding paragraphs, the profits to be attributed to the permament establishment shall be determined by the same method year by year unless there is good and sufficient reason to the contrary.

7. Where profits include items of income which are dealt with separately in other Articles of this Convention, then the provisions of those Articles shall not be affected by the provisions of this Article."

41 See, e.g., Convention With the Federal Republic of Germany for the Avoidance of Double Taxation, July 22, 1954, art. III [1954] 3 U.S.T. \& O.I.A. 2768, 2778, T.I.A.S. No. 3133: "(1) Industrial or commercial profits of an enterprise of one of the contracting States shall not be subject to tax by the other State unless the enterprise is engaged in trade or business in such other State through a pennanent establishment situated therein. If it is so engaged, such other State may impose its tax upon the entire income of such enterprise from sources within such State and will limit its taxation of the enterprise to mcome from such sources.

(2) No account shall be taken in determining the tax in one of the contracting States of the mere purchase of merchandise therem by an enterprise of the other State.

(3) Where an enterprise of one of the contracting States is engagd in trade or business in the territory of the other contracting State througl a permanent establishment situated therein, there shall be attributed to such permanent establishment the industrial or commercial profits which it might be expected to derive if it were an independent enterprise engaged in the same or similar activities under the same or similar conditions and dealing at ann's length with the enterprise of which it is a pernanent establishment.

(4) In the determination of the industrial or commercial profits of the permanent establishment there shall be allowed as deductions all expenses which are reasonably allocable to the pernanent establishment, including executive and general administrative expenses so allocable.

(5) The competent authorities of the two contracting States may lay down rules by agreement for the apportionment of industrial or commercial profits."

42 See, e.g., Convention With the United Kingdom for the Avoidance of Double Taxation, April 16, 1945, art. III, 60 Stat. 1377, 1380, T.I.A.S. No. 1546.

43 See EHREnzweig \& Koch, Income Tax Treaties 102 (1949). 
article. ${ }^{44}$ The draft proposal appears to the author to be equitable. We should not marshal exempt or limited rate items and fully tax them on the basis of the existence of a permanent establishment when these items have no causal relationship with the activities of that establishment.

Article 7 also sets forth the criterion for attributing income to the permanent establishment of a foreign enterprise-that portion of the total enterprise profit which the permanent establishment would have enjoyed if it were a distinct and separate enterprise operating in the contracting country. The commentary indicates that normally this will coincide with the accounting allocation of profits but that if an accurate result is not thereby produced adjustments may be made by the taxing authorities. ${ }^{45}$ Section 482 of the Internal Revenue Code of 1954 confers a similar power on the United States Internal Revenue Service and many of our double taxation treaties also confer such a power. Although the Internal Revenue Service has had some difficulty in the past in obtaining court approval of its application of section $482,{ }^{46}$ there have not been serious difficulties im applying the allocation provision in the treaties. Discussion with tax authorities in some European countries, however, indicates a reluctance to apply this provision due to the refusal of their courts to uphold the proposed reallocation. ${ }^{47}$ As a result there have until very recently been few attempts to reallocate income by European countries having double taxation treaties with the United States. The draft proposal would very clearly enunciate the authority for reallocation and should be acceptable to all contracting countries. There may be a problem in obtaining the necessary information for such reallocation where the internal law does not set up the machinery, but this problem should be comparatively easy to solve by simple amendments to internal law. Denmark recently embarked on an effort to secure detailed information from representatives of foreign corporations operating in Denmark and early discussions of that effort indicated the need for more definitive provisions for requiring compliance.

Article 7 endeavors to clarify the problem of which indirect expenses are attributable to the operation of a permanent establishment. One example of this type of expenditure is set out in the article, i.e., executive and general administrative expenses. Although some of the inore recently negotiated treaties have recognized a need for this type of provision, ${ }^{48}$

44 OECD Report 19.

45 Id. at 82.

46 See Cooper Agency, 33 T.C. 709 (1960); Seminole Rock \& Sand Co., 19 T.C. 259 (1952). But see Advance Machinery Exch., Inc. v. Commissioner, 196 F.2d 1006 (2d Cir. 1952).

47 Conference with Commissioner Torgeson, Tax Administration, Oslo, Norway.

48 Convention With the Federal Republic of Germany for the Avoidance of Double Taxation, July 22, 1954, art. III (4) [1954] 3 U.S.T. \& O.I.A. 2768, 2780, T.I.A.S. No. 3133. 
many of our treaties contain no statement at all relating to the deduction of these indirect expenses. ${ }^{49}$ Although this has not been a serious problem, there have been some complaints by United States enterprises of inconsistency on the part of foreign tax authorities.

As the draft commentaries note, there is no single formula for allocation of profits and expenses and the language of the draft is, to some extent, general in order to leave adequate scope for separate allocation or arbitration rules in bilateral treaties. The suggestion is raised in the commentary $^{50}$ that one possible scheme would be the adoption of the type of formula allocation used by the states of the United States for allocation of income of unitary busmesses for income tax purposes. Although this is one possible answer, the problems which have faced state tax authorities and corporate tax managers and the diversity of methods and interpretations now used by our states suggests that this may not be an "ideal" solution for international treaties, especially in view of the additional difficulties of valuation and currency adjustment. On the other hand, it is true that one of the nuost consistent criticisms of the three factor formula used by nost states has been its failure to consider the special situations applicable to the problems of particular taxpayers, and article 7 appears to be sufficiently broad to ineet this difficulty.

Paragraph 6, of article 7 provides that the same method of profit attribution should be used each year in the absence of a substantial reason for change. The purpose of this provision is to achieve certainty. Although the United States treaties do not contain such a provision, the normal operation of Umited States tax laws would require this consistency and there is no evidence that our tax authorities have been guilty of any inequitable actions in this regard.

Article 8 provides for taxing profits from the operation of ships and aircraft by the country in which the "place of effective management" is located ${ }^{61}$ Special provisions for ships and aircraft are found in some United

49 See, e.g., Convention With the Netherlands for the Avoidance of Double Taxation, April 29, 1948, art. III, 62 Stat. 1757, 1759, T.I.A.S. No. 1855.

50 OECD Report 87.

51 Id. at 46. "Article 8-Shipping, Inland Waterways Transport and Air Transport 1. Profits from the operation of ships or aircraft in international traffic shall be taxable only in the Contracting State in which the place of effective management of the enterprise is situated. 2. Profits from the operation of boats engaged in inland waterways transport shall be taxable only in the Contracting State in which the place of effective management of the enterprise is situated.

3. If the place of effective management of a shipping enterprise or of an inland waterways transport enterprise is aboard a ship or boat, then it shall be deemed to be situated in the Contracting State in which the home harbour of the ship or boat is situated, or, if there is no such home harbour, in the Contracting State of which the operator of the ship or boat is a resident." 
States conventions. For exanple, article IV of the United States-Norway Convention ${ }^{52}$ provides that "income which an enterprise of one of the contracting states derives from the operation of ships or aircraft shall be exempt from taxation in the other contracting state." These provisions have been limited in their application to the income from the direct operation of the ships or aircraft.

The commentary ${ }^{53}$ states that it is the intent of the draft to cover profits fronl activities closely connected with the direct operation of the ships or aircraft, such as bus service between the airport and a city, advertising revenue, and similar items, but which do not constitute a clearly separate enterprise such as, for example, operation of a hotel. One difficulty is that the language of the draft gives no indication of the extent of this inclusion. A much more explicit statement would appear to be necessary. This writer is not aware of the extent of importance of these collateral or associated activities, but it is probable that the main reason for the proposal to allocate them to the "place of effective management" is the difficulty of accounting. The use of the term "place of effective management" may eliminate some of the litigation and administrative difficulty which the use of the terms "home port," "state in which the enterprise is situated," or "state of registry" have engendered. It may, however, set in motion a whole category of new problems unless a clear definition is imitially adopted. For example, what is the "place of effective management" of the oil tankers of an international oil company with directors scattered over the globe and "home offices" of the parent and a inyriad of subsidiaries in numerous countries with complete transferability of the tankers between the various subsidiaries?

Article 9 provides for a reallocation of profits for tax purposes if controlled or affiliated enterprises make arrangements which cause an unrealistic profit allocation..$^{54}$ This type of provision is currently in many

52 Convention With Norway for the Avoidance of Double Taxation, June 13, 1949, art. V

[1951] 2 U.S.T. \& O.I.A. 2323, 2327 T.I.A.S. No. 2357.

53 OECD Report 90.

64 Id. at 47. "Article 9-Associated Enterprises

Where

a) an enterprise of a Contracting State participates directly or indirectly in the management, control or capital of an enterprise of the other Contracting State, or

b) the same persons participate directly or indirectly in the management, control or capital or an enterprise of a Contracting State and an enterprise of the other Contracting State,

and in either case conditions are made or imposed between the two enterprises in their commercial or financial relations which differ from those which would be made between independent enterprises, then any profits which would, but for those conditions, have accrued to one of the enterprises, but, by reason of those conditions, have not so accrued, may be included in the profits of that enterprise and taxed accordingly." 
United States conventions ${ }^{55}$ and is essential to prevent collusive arrangements between controlled or affiliated enterprises.

Draft article 10 recognizes the difficulty of arriving at a uniform solution of the problem of tax treatment of international dividend payments. ${ }^{50}$ Discussion with foreign tax authorities and with representatives of foreign enterprises lias revealed that this is one area which is the subject of constant complaint in connection with income tax conventions. Part of the problem arises because company profits in some countries are taxed at different rates depending on whether they are distributed or are held in the company. In Germany, for example, distributed profits are taxed at 15 per cent while undistributed profits are taxed at 51 per cent. Part of the problem is that the internal laws of some countries tax dividends from

55 See, e.g., Convention With the United Kingdonl for the Avoidance of Double Taxation, April 16, 1945, art. IV, 60 Stat. 1377, 1380, T.I.A.S. No. 1546: "Where an enterprise of one of the Contracting Parties, by reason of its participation in the management, control or capital of an enterprise of the other Contracting Party, makes with or imposes on the latter, in their commercial or financial relations, conditions different from those which would be made with an independent enterprise, any profits which would but for those conditions have accrued to one of the enterprises but by reason of those conditions have not so accrued, may be included in the profits of that enterprise and taxed accordingly."

50 OECD Report 47-48. "Article 10-Dividends

1. Dividends paid by a company which is a resident of a Contracting State to a resident of the other Contracting State may be taxed in that other State.

2. However, such dividends may be taxed in the Contracting State of which the company paying the dividends is a resident, and according to the law of that State, but tbe tax so charged shall not exceed:

a) 5 per cent of the gross amount of the dividends if the recipient is a company (excluding partnership) which holds directly at least 25 per cent of the capital of the company paying the dividends;

b) in all other cases, 15 per cent of the gross amount of the dividends.

The competent authorities of the Contracting States shall by mutual agreement settle the mode of application of this limitation.

This paragraph shall not affect the taxation of the conpany in respect of the profits out of which the dividends are paid.

3. The term 'dividends' as used in this Article means income froin shares, 'jouissance' sbares or 'jouissance' rights, mining shares, founders' shares or other rights, not being debt-claims, participating in profits, as well as income from other corporate rights assimilated to income fron shares by the taxation law of the State of which the company making the distribution is a resident.

4. The provisions of paragraphs 1 and 2 shall not apply if the recipient of the dividends, being a resident of a Contracting State, has in the other Contracting State, of which the company paying the dividends is a resident, a permanent establishment with which the holding by virtue of which the dividends are paid is effectively connected. In such a case, the provisions of Article 7 shall apply.

5. Where a company which is a resident of a Contracting State derives profits or income from the other Contracting State, that other State may not impose any tax on the dividends paid by the company to persons who are not residents of that other State, or subject the company's undistributed profits to a tax on undistributed profits, even if the dividends paid or the undistributed profits consist wholly or partly of profits or income arising in such other State." 
resident companies at the source while nonresidents are not taxed at all on dividends. ${ }^{57}$

Article 10 substantially adopts the principle found in most United States conventions - that the country of residence of the payee has the right to tax dividend income, with a limited right to tax reserved to the country of source. ${ }^{58}$ Although the draft does not attempt to suggest the type or rate of tax to be imposed on dividends by the country of source, it does contain maximum rates. Within those limits the present system of individual country negotiation is retamed. The commentary suggests that it may be appropriate when negotiating specific conventions to provide methods of preventing misuse of the convention to avoid taxes on dividend income. ${ }^{59}$ Thus it is suggested that the maximum rate restrictions may be made specifically inapplicable to a conpany receiving dividends if all of its sliareholders are non-residents of the State in which the company is resident, it does not distribute its profits, and it enjoys preferential tax treatment in the country of its residence. This type of operation, especially with Swiss "base companies," prompted efforts by the United States Treasury Department to prevent the use of "tax havens" and culminated in the enactment by the United States Congress of the controlled foreign corporation provisions of the Revenue Act of $1962.6^{60}$ Numerous instances of actual or attempted abuse of the tax conventions were cited to the writer by European tax authorities and the commentary suggestion merits serious consideration if a provision can be drafted which will achieve the result without inpeding legitimate operations. The 1962 Internal Revenue Code provisions, for Umited States shareholders, will prevent much of the abuse, but it is obvious that there are many methods of avoiding inclusion in these provisions and there is no question but that ingemious tax experts have already devised methods to circumvent the intent of the 1962 amendments, at least in some aspects. The difficulty inherent in the draft proposal for dividends is mdicated by the fact that ten countries liave imdicated reser-

57 The difficulty of drafting a uniform method for handling the taxation of dividends to nonresidents has always been present. In 1923 the League of Nations committee considered the problem and in 1928 proposed three alternative methods. The Mexico and London model drafts of 1943 and 1946 give a different solution than that proposed by the League and in the conventions executed subsequent to these proposals numerous variants have appeared depending largely on the special problems and negotiating power of the contracting countries involved.

58 See, e.g., Convention With Pakistan for the Avoidance of Double Taxation, July 1, 1957, art. VII [1959] 1 U.S.T. \& O.I.A. 984, 989, T.I.A.S. No. 4232: “1. Dividends paid by a company which is a resident of Pakistan shall be exempt from United States tax except where the recipient thereof is a citizen or resident or corporation of the United States. 2. Dividends paid by a Umited States corporation shall be exempt from Pakistan tax except where the recipient thereof is resident in Pakistan."

59 OECD Report 106.

6076 Stat. 1006 (1962), INT. Rev. Code of 1954, \$\$ 951-64. 
vations to one or more provisions of this article. As the commentary states, there is no effort to solve the problems which the differences in internal tax law bring about. These must be solved, as far as possible, through bilateral negotiation.

The same basic principle is used in article 11 of the draft in regard to interest. Under article 11, interest may be taxed in the state of residence of the recipient with the state of source having a right to tax up to a maximum of 10 per cent. ${ }^{61}$ Special provisions are made for exceptions when interest is effectively related to a permanent establishment or where an excessive rate of interest is determined because of the relationship between the payor and payee. The United States conventions, with a few exceptions, have exempted interest from tax by the source State when the payor is controlled by the payee. ${ }^{62}$ However, in some cases, such as the treaty

61 OECD Report 48. "Article 11-Interest

1. Interest arising in a Contracting State and paid to a resident of the other Contracting State may be taxed in that other State.

2. However, such interest may be taxed in the Contracting State in which it arises, and according to the law of that State, but the tax so charged shall not exceed 10 per cent of the amount of the interest. The competent authorities of the Contracing States shall by inutual agreement settle the mode of application of this limitation.

3. The term 'interest' as used in this Article means income froin Government securities, bonds or debentures, whether or not secured by nortgage and whether or not carrying a right to participate in profits, and debt-claims of every kind as well as all other income assimilated to income from money lent by the taxation law of the State in which the income arises.

4. The provisions of paragraphs 1 and 2 shall not apply if the recipient of the interest, bcing a resident of a Contracting State, bas in the other Contracting State in which the interest arises a permanent establishment with which the debt-claim from which the interest arises is effectivcly connected. In such a case, provisions of Article 7 shall apply.

5: Interest shall be deemed to arise in a Contracting State when the payer is that State itself, a political subdivision, a local authority or a resident of that State. Where, however, the person paying the interest, whether he is a resident of a Contracting State or not, has in a Contracting State a permanent establishment in connection with which the indebtedness on which the interest is paid was incurred, and such interest is borne by such permanent establishment, then such interest shall be deemed to arise in the Contracting State in which the permanent establishment is situated.

6. Where, owing to a special relationship between the payer and the recipient or between both of thein and some other person, the amount of the interest paid, having regard to the debt claim for which it is paid, exceeds the amount which would have been agreed upon by the payer and the recipient in the absence of such relationship, the provisions of this Article shall apply only to the last inentioned amount. In that case, the excess part of the payments shall remain taxable according to the law of each Contracting State, due regard bcing had to the other provisions of this Convention."

62 See, e.g., Convention with Denmark for the Avoidance of Double Taxation, May 6, 1948, art. VIII, 62 Stat. 1730, 1733, T.I.A.S. No. 1854: "Interest on bonds, securities, notes, debentures, or on any other form of indebtedness derived froin sources within one of the contracting States by a resident or corporation or other entity of the other contracting State not having a permanent establishment in the former State shall be exempt from tax by such former State." 
with France, the State of source is given the right to tax with a maximum limit as to rate. ${ }^{63}$

Article 12 covers royalties. ${ }^{84}$ In general, the United States conventions exempt from tax by a contracting State royalties paid by a resident of that State to the patent owner who is a resident of another State. This exemption is inapplicable if the patent owner has a permanent establishment in the State of the residence of the payor. This basic concept is adopted by article 12. The most important portion of article 12, however, is the definition of royalties in paragraph 2. The United States conventions and those of many other countries contain no definition of royalty. An increasing source of resentment has been the variations in the interpretation of the term royalty as used in the conventions. This has been increasingly true as more licenses have included agreements for furnishing "know how." These agreements have in some instances provided for a separate monetary consideration for the "know how" while in others it has been included, without ,specification, in the basic licensing payment provision. Some countries have taken the position that payments for "know how" are not payments in the nature of royalties and are not subject to the exemption fron or limitation of tax under the particular convention. The draft article includes in its definition of royalty payment for "information concerning industrial, commercial or scientific experience." This makes clear that "know how" payments are royalties and are to be treated accordingly. The draft also contains provisions similar to those in article 11 when royalties are received which relate to the activities of a permanent establishment in

63 Convention With France for the Avoidance of Double Taxation, July 25, 1939, art. VI, 59 Stat. 893, 897, T.S. No. 988, as amended, June 22, 1956 [1957] 1 U.S.T. \& O.I.A. 843, 845 T.I.A.S. No. 3844.

04 OECD Report 49. "Article 12-Royalties

1. Royalties arising in a Contracting State and paid to a resident of the other Contracting State shall be taxable in that other State.

2. The term 'royalties' as used in this Article means payments of any kind received as a consideration for the use of, or the right to use, any copyright of literary, artistic or scientific work including cinematograph films, any patent, trade mark, design or model, plan, secret formula or process, or for the use of, or the right to use, industrial, commercial, or scientific equipment, or for information concerning industrial, commercial or scientific experience.

3. The provisions of paragraph I shall not apply if the recipient of the royalties, being a resident of a Contracting State, las in the other Contracting State in which the royalties arise a permanent establishment with which the right or property giving rise to the royalties is effectively connected. In such a case, the provisions of Article 7 shall apply.

4. Where, owing to a special relationship between the payer and the recipient or between both of them and some other person, the amount of the royalties paid, having regard to the use, right or information for which they are paid, exceeds the amount which would have been agreed upon by the payer and the recipient in the absence of such relationship, the provisions of this Article shall apply only to the last-mentioned amount. In that case, the excess part of the payments shall remain taxable according to the law of each Contracting State, due regard being had to the other provisions of this Convention." 
the State of source. This appears to be an appropriate exception to the royalty rule and by implication prevents the inclusion of royalty income unrelated to a permanent establishment. Paragraph 4 allows for reallocation of a portion of alleged royalty income when a special relationship has resulted in an unrealistic royalty agreement.

The great diversity of definition and methods of taxing capital gains accounts for the generality of the provisions of article $13 .{ }^{65}$ The United States conventions vary, largely on the basis of internal tax law differences, in the treatment of capital gains taken in the other contracting country from that provided under the United States Internal Revenue Code. ${ }^{00}$ For example, the United States-United Kingdom treaty ${ }^{67}$ exempts gains from the sale in the United States of capital assets by a resident of the United Kingdom who is not engaged in a trade or business in the United States, thus accepting the United Kingdom's treatment of capital gains as not subject to income tax. Our treaty with Japan taxes capital gains from the sale of personal property as income taxable in the country where the property is sold while gains from the sale of real property are treated as arising in the country where the property is situated. ${ }^{68}$ The draft proposal commentary emphasizes the differences in the treatment of capital gains in the various member countries and the resultant problenı of setting forth an acceptable uniform rule. That uniformity is nearly impossible is illustrated by the United States' reservation of the right not only to tax its own citizens and corporations on gams from the sale of property wherever situated but also the right to tax non-resident aliens on capital gains from the sale of personal property if the non-resident is in the United States at the

65 Id. at 49. "Article 13-Capital Gains

1. Gains from the alienation of immovable property, as defined in paragraph 2 of Article 6 , may be taxed in the Contracting State in wlich such property is situated.

2. Gaims from the alienation of movable property forming part of the business property of a permanent establishment which an enterprise of a Contracting State has in the other Contracting State or of movable property pertaining to a fixed base available to a resident of a Contracting State in the other Contracting State for the purpose of performing professional services, including such gains from the alienation of such a permanent establishment (alone or or together with the whole enterprise) or of such a fixed base, may be taxed in the other State. However, gains from the alienation of movable property of the kind referred to in paragraph 3 of Article 22 shall be taxable only in the Contracting State in which such movable property is taxable according to the said Article.

3. Gains from the alienation of any property other than those mentioned in paragraphs 1 and 2, shall be taxable only in the Contracting State of which the alienator is a resident."

66 INT. REv. CODE of 1954, \$\$ 1201-23.

67 Convention with the United Kingdom for the Avoidance of Double Taxation, April 16, 1945, art. XIV, 60 Stat. 1377, 1384, T.I.A.S. No. 1546.

68 Convention with Japan for the Avoidance of Double Taxation, April 16, 1954, art. XIII [1955] 1 U.S.T. \& O.I.A. 149, 161 T.I.A.S. No. 3176, as amended, March 23, 1957 [1957] 2 U.S.T. \& O.I.A. 1445, T.I.A.S. No. 3901. 
time of a sale "or under other circumstances described in its law." 69 We are thus left under the draft with all the questions of application or nonapplication of the internal law on taxation of capital gains that are present in the treaties now in effect. It would appear that the only feasible solution is a planned non-uniformity. One suggestion is that in any convention to which the United States is a signatory, paragraphs 1 and 2 of article 13 should be adopted but there should be the additional proviso that there should not be, for United States citizens and residents, exclusion from United States tax liability unless the gain has been subjected to liability for tax in the other contracting state, whether in fact tax actually was imposed. This would preclude the use of non-capital gain countries for the sale of property to avoid tax imposition in the United States. ${ }^{70}$

Article 14 embodies the principle that the "independent professional," that is, the lawyer, doctor, engineer, teacher, or scientist is taxed only by his country of residence unless he has a "fixed base" in the country in which the services are rendered. ${ }^{71}$ The commentary indicates that a fixed base would include a lawyer's office, physician's consulting room, or similar facility. ${ }^{72}$ This is a much broader provision than is found generally in United States treaties. Except in a few treaties, such as the one with France, ${ }^{73}$ there is no general professional activity provision and any exemption, with the exception of teachers, is covered under a limited personal services provision. Further, the teacher provision in United States treaties usually has a two-year time limitation. The draft provision apparently

69 OECD Report 129.

70 Rev. Rul. 56-446, 1956-2 CuMr. Bur.c. 1065; Rev. Rul. 58-247, 1958-1 CuM. BuLL. 623 (Canadian Treaty) ; Lewenhaupt v. Commissioner, 221 F.2d 227 (9th Cir. 1955). See Maximov v. United States, 373 U.S. 49 (1963), noted in 51 CaIrF. L. REv. 792 (1963).

71 OECD Report 50. "Article 14-Independent Personal Services

1. Income derived by a resident of a Contracting State in respect of professional services or other independent activities of a similar character shall be taxable only in that State unless he has a fixed base regularly available to him in the other Contracting State for the purpose of performing his activities. If he has such a fixed base, the income may be taxed in the other Contracting State but only so much of it as is attributable to that fixed hase.

2. The term 'professional services' includes, especially independent scientific, hterary, artistic, educational or teaching activities as well as the independent activities of physicians, lawyers, engineers, architects, dentists and accountants."

Compare this provision with Treaty With France for the Avoidance of Double Taxation, July 25, 1939, art. X, 59 Stat. 893, T.S. No. 988: "Income from the exercise of a hberal profession shall be taxable only in the State in which the professional activity is exercised.

There is the exercise of a hiberal profession in one of the two Contracting States only when the professional activity has a fixed center in that country."

Article I(4) of the supplementary protocol signed May 17, 1948, effective January 1, 1950, provides that Article $X$ shall be applied on a reciprocal basis.

72 OECD Report 130.

73 Convention with France for the Avoidance of Double Taxation, July 25, 1939, art. 10, 59 Stat. 893,899 , T.S. No. 988. 
embodies an acceptance of the speed of modern travel and of the possibility of frequent activities by the professional in countries other than that in which he has his place of business. The broad definition of "professional services" would also eliminate an annoying interpretation by the United States authorities of the teacher provision. The Internal Revenue Service takes the position that in order to come within a teacher provision, the individual must actually have students and that a researcher at a University, even though a qualified professor, is not entitled to the benefit of the clause. ${ }^{74}$ The result has been some hardship cases and undoubtedly much maneuvering by educational institutions. The broad definition in article 14 is practical and equitable.

Article 15 relates to personal services rendered as an employee and embodies generally the language found in most presently effective double taxation conventions. ${ }^{75}$ It adds, however, two items not found in most conventions. It exempts from taxation by State $X$ income earned by a resident of State $Y$ for the rendition of personal services in State $X$ if he is in State $X$ not more than 183 days in the fiscal year, is paid by or on behalf of a non-resident employer, and the remuneration is not borne by a permanent establishment or fixed base of the employer in the contracting state. Most of the clauses now in effect use the 183 day provision but require that the services be rendered for or on behalf of an employer resident in the einployee's state of residence. In addition, when burden of the remuneration is relevant the normal provision is that it must be borne by the employer. Under the draft proposal an individual, a resident of a treaty country, could work in the United States on loan from a non-treaty country eniployer, with the United States corporation paying the remuneration as agent of the employer who in fact bears no part of the burden.

74 Rev. Rul. 60-23, 1960-1 CuM. Bunc. 754.

75 OECD Report 50. "Article 15-Dependent Personal Services

1. Subject to the Provisions of Articles 16,18, and 19, salaries, wages and other similar remuneration derived by a resident of a Contracting State in respect of an employment shall be taxable only in that State unless the employment is exercised in the other Contracting State. If the employment is so exercised, such remuneration as is derived therefrom may be taxed in that other State.

2. Notwithstanding the provisions of paragraph 1, remuneration derived by a resident of a Contracting State in respect of an employment exercised in the other Contracting State shall be taxable only in the first-mentioned State if:

a) the recipient is present in the other State for a period or periods not exceeding in the aggregate 183 days in the fiscal year concerned, and

b) the remuneration is paid by, or on behalf of, an employer who is not a resident of the other State, and

c) the remuneration is not borne by a permanent establishment of a fixed case which the employer has in the other State.

3. Notwithstanding the preceding provisions of this Article, remuneration in respect of an employment exercised aboard a ship or aircraft in international traffic, or aboard a boat engaged in inland waterways transport, may be taxed in the Contracting State in which the place of effective management of the enterprise is situated." 
Under the burden clause now used in some of our treaties, tax authorities in some countries hold that if the employment contract provides that the local employer is to pay, on behalf of the general employer, a specified amount to the employee which is in fact equal to his normal remuneration, the general employer is not bearing the burden of the remuneration. The draft clause would appear to require an opposite conclusion.

Article 16 allows the taxation of directors' fees in the State in which the company is resident. ${ }^{76}$ Most United States conventions do not contain a provision specifically covering this group of individuals and it would appear to have little effect on United States taxation of its citizens and residents.

Article 17 provides that the income of entertainers is taxable where they exercise their personal activities. ${ }^{77}$ Thus the entertainer is excluded from the remedial provisions of article 15. In view of the storm which was caused by exclusion of the entertainer in the treaty with the Umited Kingdom, this exclusion is not acceptable to the United States, and a reservation was made by our representatives. ${ }^{78}$ The commentary suggests, however, the possibility of distinguishing between independent entertainers and employees such as motion picture actors and covering the latter under article $15 .^{79}$

Article $18^{80}$ allows only the payor State to tax payments, including pensions, paid by governmental authorities for services rendered to the government. $^{81}$

${ }^{76}$ Id. at 51. "Article 16-Directors' Fees

Directors' fees and similar payments derived by a resident of a Contracting State in his capacity as a member of the board of directors of a company which is a resident of the other Contracting State may be taxed in that other State."

77 Ibid. "Article 17-Artists and Athletes

Notwithstanding the provisions of Articles 14 and 15, income derived by public entertainers, such as theatre, motion picture, radio or television artists, and musicians, and by athletes, froin their personal activities as such may be taxed in the Contracting State in which these activities are exercised."

78 See Report of Subcomm. on Executtve Decistons, Senate Comm. on Foretgn Rezatrons, 79th Cong. 1st Sess. reprinted in 2 State of Jonst Comsr. on INT. Rev. Taxatron, Legislattve History of U.S. TAX Conventions 2722 (1962).

79 OECD Report 134.

${ }^{80}$ Id. at 51. "Article 18-Pensions

Subject to the provisions of paragraph 1 of Article 19, pensions and other similar remuneration paid to a resident of a Contracting State in consideration of past employment shall be taxable only in that State."

81 Ibid. "Article 19-Governmental Functions

1. Remuneration, including pensions, paid by, or out of funds created by, a Contracting State or a political subdivision or a local authority thereof to any individual in respect of services rendered to that State or subdivision or local authority thereof in the discharge of functions of a governmental nature nnay be taxed in that State.

2. The provisions of Articles 15,16 and 18 shall apply to remuneration or pensions in respect of services rendered in connection with any trade or business carried on by one of the Contracting States or a political subdivision or a local authority thereof." 
Article 20 gives an exemption to students for income from sources outside the State in which they are studying. ${ }^{82}$ It is not substantially different $\mathrm{m}$ principle from provisions found in most United States treaties.

Article 21 gives the State of residence the exclusive right to tax items of income not expressly provided for in the convention. The general United States reservation would undoubtedly apply here and it is interesting to note that Canada has reserved the right to tax amounts paid by Canadian residents to non-residents for alimony, trust or estate, and other income.

Articles $23 \mathrm{~A}$ and $\mathrm{B}^{83}$ cover two methods for elimination of double taxation of income. The first is the exemption method which is presently used by a number of European States. Under this method the income is exempt from tax although it may be used in determining the rate of tax upon taxable income. This clause also requires an appropriate deduction allowance from tax for the tax paid to the other State upon dividends or interest. The second method, the credit, is the method used by the United States. ${ }^{84}$

Article 24 is intended to prevent discrimination against the nationals of one contractimg State by the other. ${ }^{85}$ This clause is intended to remove

82 Id. at 52. "Article 20-Students

Payments which a student or business apprentice who is or was formerly a resident of a Contracting State and who is present in the other Contracting State solely for the purpose of his education or training receives for the purpose of bis maintenance, education or training shall not be taxed in that other State, provided that such payments are made to him froin sources outside that other State."

83 Id. at 140.

84 INr. Rev. CODE of $1954 \$ \$ 33,901$. See Block \& Heilemann, International Tax Relations, 55 YALE L.J. 1158, 1163 (1946), where he states his opinion that exemption method increases the possibility of tax avoidance.

85 OECD Report 55. "Article 24-Non-Discrimination.

1. The nationals of a Contracting State shall not be subjected in the other Contracting State to any taxation or any requirement connected therewith which is other or more burdensome than the taxation and connected requirements to which nationals of that other State in the same circumstances are or may be subjected.

2. The term 'nationals' means:

a) all individuals possessing the nationality of a Contracting State;

b) all legal persons, partnerships and associations deriving their status as such from the law in force in a Contracting State.

3. Stateless persons shall not be subjected in a Contracting State to any taxation or any requirement connected therewith which is other or more burdensome than the taxation and connected requirements to which nationals of that State in the same circumstances are or may be subjected.

4. The taxation on a permanent establishment which an enterprise of a Contracting State has in the other Contracting State shall not be less favourably levied in that other State than the taxation levied on enterprises of that other State carrying on the same activities.

This provision shall not be construed as obliging a Contracting State to grant to residents of the other Contracting State any personal allowances, reliefs and reductions for taxation purposes on account of civil status or family responsibilities which it grants its own residents.

5. Enterprises of a Contracting State, the capital of which is wholly or partly owned or controlled, directly or indirectly, by one or more residents of the other Contracting State, 
many special privileges which the State accords its own nationals or enterprises and to require the same treatment of an enterprise of the treaty State as is afforded to its own enterprises. This might preclude the use of the flat 30 per cent rate on non-resident aliens with income under 15,400 dollars in the Uurited States.

The remaining clauses on such matters as neutral agreement procedure and exchange of information are very similar to provisions presently found in most conventions, and might be called boilerplate. They are inportant, however, because they have been the basis of cooperative action which has assisted the administration of the treaties and avoided mequitable situations arising in some of the diffcult areas not specifically covered by a particular treaty provision. ${ }^{88}$

\section{CONCLUSION}

The Uurited States has been in the tax treaty business for over 25 years. There are soine who believe that it has been a somewhat wasted effort on the part of those who have encouraged negotiation of these agreements. Others believe that although the treaties serve some purpose in a mimimal number of cases, the foreign tax credit provisions inake the treaties of little real value ${ }^{87}$ Some of those indicating the need for more taxpayer relief were proponents of the tax sparing provisions which were sought to be included in the Pakistan and other recently negotiated treaties. These provisions would, of course, have given the internal tax law of Pakistan an overriding position over United States tax law in order to make the special tax sparing provisions meaningful for United States businesses. However, some tax experts, notably Secretary Surrey, took strong exception to the provisions as a matter of principle ${ }^{88}$ and Congress was not disposed to allow, in effect, another nation's special inducements to Aunerican industry to negate the basic United States premise of taxation of citizens and residents on their entire income. Other writers have raised questions as to the ends sought to be achieved by tax treaties and have suggested that we are using an approach that does not serve those ends..$^{89}$ One article has raised some thirty or more questions to be answered in an effort to

shall not be subjected in the first-mentioned Contracting State to any taxation or any requirement connected therewith which is other or more burdensome than the tasation and connected requirements to which other similar enterprises of that first-mentioned State are or nay be subjected.

6. In this Article the term 'taxation' means taxes of every kind and description."

80 See Block \& Heilemann, supra note 84 .

87 Owens, Role of the United States Income Tax Treaties in Relieving Double Taxation, 4 Institute on PrJvate Investarents Abroad 109, 112 (1962).

88 Surrey, The Pakistan Tax Treaty and Tax Sparing, 11 NaT'x Tax J. 1156 (1958).

${ }^{89}$ See, e.g., Owens, supra note 87. 
determine how and whether treaties can or should be used to meet problems of tax policy and gold retention..$^{90}$ There is no dearth of discussion and suggestion in this area of tax law and much of it would indicate that the tax treaties presently in force serve little useful purpose for United States taxpayers.

There are, however, unany indications that the treaties are useful, if only psychologically, for the expansion of world trade and consequently world communication. The existence of treaties has had some advantageous effects in drawing the treaty countries into a closer relationship and this alone appears to be of important value. In addition, the treaties have had some influence in attracting foreign capital to the United States and in removing some of the administrative irritants which the overlapping of income tax laws makes inevitable. The evidence is very convincing that the cooperation provisions have allowed the solution of many difficult double taxation situations and thus have favorably influenced our international relationships. In addition an expansion of coverage of the treaties to special situations, as for example the question of alimony payments, could eliminate many insignificant but irritating problems. ${ }^{91}$

It is the opinion of this writer that although the tax credit makes double inconie taxation an infrequent occurrence for the United States taxpayer, the treaties are valuable in many ways to the United States citizen or corporation doing busmess in treaty countries. In many cases they do (or should) eliminate the difficult question of what constitutes a tax in lieu of a tax on inconie, war profits, or excess profits which is the requirement for the credit for foreign taxes under the Internal Revenue Code. ${ }^{92}$ The treaties materially reduce record keeping for individual and corporate taxpayers and more importantly elimmate much of the argument over tax hability. They can (and should) eliminate the divergent definitions of residence, source of inconie, royalties, and other troublesome terms which, without the treaties, are defined by local law and result in double taxation and double irritation. The treaties are especially helpful in encouraging capital from countries which do not have a credit provision. Properly drafted, they will eliminate the exemption froun all tax which a lack of uniformity of definition and interpretation of tax terms has and will continue to make possible. ${ }^{93}$ They can, should, and will dispel unuch of the confusion, frustration, and irritation which contact by businessmen with United States or European tax authorities is bound to engender.

90 Anthoine \& Block, Tax Policy and the Gold Problem, 61 Colum. L. Rev. 322 (1961).

91 The writer in his interviews with tax officials in the United Kingdom, France, Switzcrland, Austria, Germany, Belgium, Denmark, Norway and Sweden, and the Netherlands as well as taxpayer representatives arrived at the conclusion that the treaties served a useful purpose.

02 INT. Rev. CODE of 1954, § 903.

93 See David Rose, 16 T.C. 232 (1951). 
In the event that there is general agreement on the provisions contained in the draft convention by the European countries participating in its construction there will of course be very substantial revision of the treaties involving these countries. The United States as a participating country will be requested and will undoubtedly wish to revise its treaties to gain the desired uniformity. The United States and, to a lesser extent, the other participating countries will be faced with the reservations which for reasons of internal law or policy they have made to the draft provisions. There is no question that uniformity of even a few of the major provisions is better than the present hodgepodge which permeates the treaties in which the United States is involved and the same is true of most of the treaties of other countries. It may be that this himited uniformity is all that can be obtamed when we are dealing with such diverse income tax systems. Of course, it is important to guard against opening the door to erosion of the tax system simply to gain uniformity. The draft convention im many respects offers an opportunity to eliminate confusion and sources of conflict by more complete definitions and the adoption of a single principle of interpretation. The United States should make every effort to join with European countries in achieving maximunl uniformity without detrimentally compromising its own tax system. 


\section{California Law Review}

MEMBER NATIONAL AND WESTERN CONFERENCES OF IAW REVIEWS

Published Five Times Yearly by Students of the School of Law of the University of California, Berkeley, California. Indexed in Index to Legal Periodicals and Public Affairs Information Service.

Subscription Price, $\$ 6.00 \quad$ Current Single Copies, $\$ 2.00$

\section{BOARD OF EDITORS}

\author{
Donald P. NewerL \\ Article Editor \\ George M. Perry \\ Article Editor \\ George W. AshFord, JR. \\ Managing Editor \\ KeNdaLI, R. Bishop \\ Research Editor \\ Miceaer R. Asmrow \\ Book Review Editor
}

JaMes R. BRidges

Stanley A. Coolidge, Jr. George F. Dunrer, Jr.

Charles A. Bell JANE R. BRADY Robert B. Chickering Daniex E. Cummins Groria F. DeHart EMrE Roy EISENEardT Jerome B. Falk, JR. BurCH H. FitzPATRICK, Jr. Joseph B. Gaudet
David H. MeLNick Editor-in-Chief

\author{
ARNold D. KaHN \\ Note \& Comment Editor \\ Robert E. Bosso \\ Note \& Comment Editor \\ M. RoOUe HeMcrey \\ Note \& Comment Editor \\ ROBERT OHLBAch \\ Note \& Coniment Editor \\ MnNot W. TRIPP, JR. \\ Note \& Comment Editor
}

\section{Associates}

Alfred N. Gertarenian

JoHN Kaged

Paul M. Little

MYron Moskovitz

\section{Candidates}

Frankin P. Glenn Strephen R. Grant Eliss J. HarmoN DARRYL A. HART VICTOR J. HAYdeL, JR. PATRICK S. HobIN Wirliajar J. Hoese BYRON B. KOHN Thomas A. Lee, JR.

Marjorie Devereux Administrative Assistant
Carl R. Pagter

Daniet I. Reith

Cameron W. Wolfe, Jr.
Douglas A. McGrev JaAres H. Newhouse David C. Nolan Noraran S. Oberstein Thegdore B. OLSON Patrick L. Shreve Walter V. Stafford Gardon H. Van Kesset, RALPH C. WAL,KER 